\title{
Speech Act of Responding to Rudeness: A Case Study of Malaysian University Students
}

\author{
Maryam Farnia (Corresponding author) \\ Payame Noor University, Iran \\ E-mail: mfarniair@gmail.com \\ Hiba Qusay Abdul Sattar \\ Australian Technical Management College (ATMC), Australia \\ E-mail: hibaqusay@yahoo.com \\ Hooi Chee Mei (Esther) \\ Universiti Sains Malaysia, Malaysia \\ E-mail: hooiesther@yahoo.com
}

Doi:10.7575/aiac.alls.v.5n.2p.46

Received: 03/02/2014

URL: http://dx.doi.org/10.7575/aiac.alls.v.5n.2p.46

Accepted: 24/03/2014

\begin{abstract}
Politeness conventions vary across cultures and so is impoliteness and rudeness. In some cases, what is considered rude in one culture or a society is not necessarily rude or impolite in another. This cannot be explained unless more studies on the use of language functions in a specific culture are conducted. The aim of this paper is to investigate Malaysians university students' realization of responding to rudeness. For this purpose, 51 Malaysian university students at Universiti Sains Malaysia took part in this research. The respondents completed a Discourse Completion Task consisting of six situations in which they had to respond to an offensive or a rude language directed toward them. The findings were then analyzed using Beebe and Waring's (2005) a coding scheme of responding rudeness to examine the type and use of strategies in responding to rudeness. Moreover, a post-structured interview was conducted to explore the respondents' perception of politeness, cognition and language of thought (i.e. the language they think in their mind to produce response in the moment) in responding to rudeness. The results showed that participants employ different strategies with variations in contextual variables (i.e. social distance and social status) in their responses. The comparison of participants' production and perception in responding to rudeness provided significant results. It is hoped that the analysis of Malaysian university students' responding to rudeness could add to the body of knowledge in pragmatics and speech act studies in general and to our understanding of Malays university students' realization in responding to rudeness in particular.
\end{abstract}

Keywords: responding to rudeness, perception, strategies, Malaysian university students

\section{Introduction}

It is not surprising that people who live in a different culture have different perceptions about how responses to an offensive situation should be performed in interpersonal communication, i.e. whether to keep silent, throw their anger, or treat nicely. This is due to the fact that culture is "composed of socially shared elements, socially shared norms, codes of behavior, values, and assumptions about the world that clearly distinguish one sociocultural group from another" (Trueba, 1993, p. 34, cited in Lee, 2003). For example, some international students might have encountered situations in which their reactions to offensive behavior made the issue more complicated. Getting into a new society, one cannot deny the importance of acquaintance and knowledge about the cultural norms and politeness conventions in that given society. What is considered polite in one society could be considered rude or impolite in another. In fact, it is hard to identify what might constitute polite or impolite behavior in social interactions. This is because politeness or impoliteness is a context-dependent evaluative judgment and linguistics constructions in themselves do not bear any property of what is being polite or rude, rather this is determined by the condition of usage (Spencer-Oatey, 2000). Similarly, Arendholz (2013) maintained that politeness is as a purely mental notion is strongly dependent on the interpreting mind in terms of scope of applicability, i.e. a person's willingness to label an utterance an action polite. In other words, politeness depends on the evaluation of individual interlocutors at individual moments in individual circumstances. Consequently, any communicative act or behavior perceived as polite or impolite may vary from community to community, from culture to culture, depending on the social context involved in the situation (Song, 2012). Several papers (Blum-Kulka, 1982; Cohen and Olshtain, 1981) have shown that norms vary from one culture to culture. It is not bound to discourse but include body language and paralinguistic features (e.g. intonation). For example, within the context of rudness or impoliteness, using index finger is acceptable to refer to people and objects in Middle East; however, it is perceived impolite in Malaysia. On the other hand, using thumbs for reference have opposite meaning in these two regions. 
Similarly, impoliteness or rudeness is very hard to be defined. "there is no solid agreement as to what "impoliteness" actually is' (Locher and Bousfield 2008, p. 3 cited in Culpeper, 2011) For example, Lakoff (1989, p.103) mentioned that "[rude behavior] does not utilise politeness strategies where they would be expected, in such a way that the utterance can only almost plausibly be interpreted as intentionally and negatively confrontational". While, for Beebe (1995, p.159) rudeness is defined as a face threatening act (FTA) - or feature of an FTA such as intonation - which violates a socially sanctioned norm of interaction of the social context in which it occurs.

The concept of rudeness is perceived differently based on the social situations in which it is employed. Some examples of rudeness are as follows: "failing to return a greetings, refusing to shake hands, swearing at someone, interrupting a speaker, talking when you should be listening, not listening when you should listen, being over-familiar, putting your finger in your nose in publics", etc. (Westacott, 2006, p. 2). These examples display the diverse representation of rudeness in our daily life. Despite the fact that rudeness is a very common act in our daily interaction, it should not be regarded as a trivial issue for it might cause more distress than injurious acts like theft or robbery.

Rudeness appears in different forms and might be judged differently in terms of rate of offensiveness. Moreover, people might also choose to reply differently in such situations in different cultures or situations. There is no rule as such to say what speech or behavior is derogatory or insulting as they are considered more or less hate speech depending on the situation, tone of voice, social status or social distance of the speakers involved in the interaction.

\section{Literature review}

The concept of speech act has been suggested by Austin (1962). It is defined as "the level [which] mediates immediately between the usual level of grammar and the rest of a speech event or situation in that it implicates both linguistic form and social norms" (Hymes, 1972, cited in Manes, 1983, p.96). According to speech act, speakers perform certain act within a speech event in a situation. For example, when a passerby asks another the time on the street, he would say, 'what time is it?' and the response would be 'It's X', and the passerby would say, 'Thank you'. With a situation like asking the time, the participants perform three speech acts: asking the time, giving the time, and thanking (Scollon and Scollon, 1997, p.17). This example shows that speakers perform and transfer language functions through speech acts in their communication. In other words, speech act theory proposed that "the minimal unit of human communication is not a sentence or other expression, but rather the performance of certain kinds of language acts, such as request and promise" ( Dietz and Widderschoven, 1991, p. 236). According to Austin (1962), there are three levels in everyone's speech: propositional meaning, that is the literal meaning of what is said, e.g. "It's cold in here", illocutionary meaning, that is the social function of what is said, e.g. "It's cold in here" could be an indirect request for someone to close the door, or to turn on the heater, or a complaint implying why someone wants to open the window, and perlocutionary meaning, that is the effect of what is said on the hearer, e.g. "It's cold in here", could result in someone turn on the heater. On the basis of these three dimensions, Searle proposed the next classes of speech. Searle classified the illocutionary act into five categories: assertive (e.g. suggesting, swearing, concluding), directives (e.g. asking, ordering, requesting, inviting, advising), commisives (e.g. promising, planning, betting), expressive (e.g. thanking, apologizing, welcoming), and declarations (e.g. changing the state of the world). Following Searle' classification of speech act, responding to rudeness is accommodated in the category of expressive. It states the speaker's psychological state, attitudes or feelings.

Speech acts can differ cross-culturally (Einstein and Bodman, 1986). The extent to which speech acts realized differently in different culture are recognized through studying speech acts to provide us with a better understanding of the relation between linguistic forms and sociocultural context (Olshtain and Cohen, 1983). Moreover, research on speech act studies can provide the appropriate sociocultural rules surrounding the utterances of native speakers (Murphey and Neu, 1996) which is the most important source and basis for sociopragmatic rules governing speech acts in the language. Using speech acts in the language of different community reflects the social norms and assumptions of that specific culture. Accordingly, when learning a foreign language, students cannot be guaranteed from miscommunication or breakdown in communication by merely mastering grammatical and lexical knowledge of that language. Hence, studies on speech act realization can mirror the potential cultural-specific language function across different culture.

\section{Speech act of responding to rudeness}

Among the few studies addressed the issue of responding to rudeness using speech act theory is Beebe and Waring's (2005) study of foreign language learners' pragmatic development in responding to rudeness. Their subjects were selected from and formed into two groups of 20 EFL students in highest and lowest language proficiency levels (total 40). The subjects were students in an English language institute in an American university in the United States. The researchers used an open-ended questionnaire in the form of Discourse Completion Task (DCT) which consisted of six situations. Beebe and Waring developed a coding scheme which divided the pragmatic strategies into three clusters: aggressing strategies (i.e. insult, threat, challenge, criticize, compliments, greet (sarcastic)), persisting strategies (i.e. argue (take issue), justify, request) and acquiescing strategies (i.e. apologize, thank, acquiesce, opt-out, nonverbal and verbal). The subjects were compared in terms of use of pragmatic development of the three clusters and their strategies in responding to rudeness with variation in their language proficiency. The findings of the study showed no differences in the type of pragmatic strategies across language proficiency, yet the language learners were different in the use (i.e. frequency) of the strategies as higher proficiency learners were more assertive in their responses and thus they were found to show a possible approximation to target-like behavior. 
In another pragmatic study of speech act of responding to rudeness, Farnia, Buckkeit and Vedaei (2010) compared American native speakers of English and Iranian native speakers of Persian. Adopted and adapted Beebe and Waning's (2005) questionnaire and coding scheme, Farnia et al. compared twenty American and twenty Iranian university students using DCT questionnaire in their respective languages. The findings showed that Americans used a greater number of strategies in responding to rudeness than their Iranian counterparts. The findings of their study displayed that criticism was the most frequently used strategy by native speakers of Farsi while insult was the most frequently used strategies by native speakers of English. Moreover, insult and argument were the second and third frequently used strategies by native speakers of Farsi, whereas their American counterparts chose argument and challenge as the second and third most frequently used strategies. Furthermore, Americans used threat strategies more frequently than Iranians. The findings also showed that native speakers of English used the strategies of apology, acquiescence and opt-out more frequently than Iranians in the DCT questionnaire. Their findings showed significant statistical differences in the use of threat, challenge and opt-out strategies between native speakers of Farsi and native speakers of English. In other words, native speakers of English used significantly more of this strategy than their Iranian counterparts.

Based on the selected studies cited above, it can be deduced that responding to rudeness like other speech act such as requests, refusals, etc. involves different types of strategies which reflects the social norms and assumptions of different communities and cultures. The speech act of responding to rudeness includes real life interactions and requires not only knowledge of the language but also appropriate use of that language within a given culture. Thus, further research may provide us with a more global view of the cultural tendencies in the act of responding to rudeness among non-native speakers like Malaysians.

\section{Malays' perception on politeness and impoliteness}

Malays' perception on politeness and impoliteness is vital to be able to know how Malays respond in different kinds of situations. Therefore, it is important to know and understand the Malays' culture, as well as, their directness and indirectness when responding to social situations.

During an act of communication, speakers resort to a variety of linguistic strategies which might save or attack the interlocutor's face, i.e. "the public self-image that every member wants to claim for himself" (Goffman, 1967, p.12). In some situations, the speaker might unintentionally choose a type of strategy which violate the addressee's social norms and expectation and as a result be considered rude or impolite.

In order to comprehend what constitutes a Malay culture, it is important to understand the "budi" concept (Storz, 1999). This means that its importance lies in giving an understanding for the politeness patterns of the Malays in Malaysia. According to Tham (1971), the ethical system of the Malays is encapsulated in the "budi" complex. It is the essence of their social relationships. It also formulates norms of individual and social behavior. The way an individual should feel and think about himself or herself and others is guided by the "budi" complex. As Dahlan (1991) stated in its general sense, "budi" embodies all the virtues ranked in the system of values of the society. The polite system of the Malays is deeply rooted in the "budi" complex. The polite system includes all aspect of verbal and nonverbal communication (Dahlan, 1991). "The way language is used, the intonations of speech and the ways people are addressed according to a status hierarchy are part of the polite system" (Storz, 199, p.119). This shows that the level of politeness is determined by the rank by the society in Malaysia.

The Malay culture emphasises self-control in the face of social conflict, hence uttering displeasure or disagreement is less likely to happen. If disclosed, they are considered uncivilised behavior, threatening individual listener's face and provides potential disrupt to the perseverance of social harmony among the speakers involved (Jamaliah Mohd Ali, 2002, 1995; Asmah Haji Omar, 1992; Asma Abdullah 1996; Teo Kok Seong, 1996, 1995). However, complaints normally happen in a social interaction among native speakers of Malay, especially among the middle class Malays (Maros, 2007).

Directness in Malay discourse could be considered impolite and uncouth, even in warning a child. Directness in discourse is perceived as being boastful and arrogant in certain contexts and in others, as being ignorant of the genteel tradition of the Malays (Teo, 1996). Malay discourse will go for some time before the real intention is made known, and even then, it will be imparted in an indirect way. The forms of utterances and the discourse structure reflect on participating parties, who take a long time in preliminaries and make hints at their responses and intentions.

Indirectness is an important theme in Malay culture. Malays rely on indirectness in many common social situations, especially when they are trying to be polite (Teo, 1996). Indirectness in Malay may be reflected in routines of offering and refusing, as well as in accepting gifts, food, and so on.

\section{The present stud}

The present study focuses on the speech act of responding to rudeness. It investigates Malaysians students, particularly Malay's perception and realization of responding to rudeness. It examines the strategies Malaysians Malay choose in the act of responding to rudeness and their perception of the situation in terms of their cognition, language of thought and their awareness of the cultural differences in responding to rudeness.

\section{Methods}

The following sections explain the methodology of this study. 


\subsection{Participants}

The participants of this study were 51 Malaysian Malay university students at Universiti Sains Malaysia through a voluntary participation, i.e. the students were asked if they are interested to fill out the questionnaire after their classes. An analysis of participants' biodata displayed that they were 21 male and 30 females, $68 \%$ of whom aged between 18 to 25 and $32 \%$ of whom aged 25 to 30 . The analysis showed that $48.40 \%$ of the respondents were pursuing their degrees while others were doing STPM/Matriculations or doing their Masters at USM. The analysis also shows that all participants' mother tongue is Malay.

\subsection{Instruments}

The instrument used for this study was a demographic survey, an open-ended questionnaire in the form of Discourse Completion Task (DCT) followed by a semi-structured interview. The demographic survey aimed to collect data on participants' age, education, gender, ethnicity, income, and where they come from. The DCT, adopted and adapted from Beeb and Waring's (2005) study of responding to rudeness, consists of six situations with variations in contextual variables (i.e. social distance and social status). The questionnaire was piloted with 10 respondents and then the situations were modified to suit the Malaysian context. The final questionnaire was translated into Malay language using a back-translation technique, i.e. the questionnaire was translated into Malay and then, an English-Malay bilingual translated the Malay version into English. According to Cohen (1996), DCT is a lucid means of data collection for pragmatic studies and if prepared carefully, it demonstrates ways in which respondents activate their pragmatic knowledge (Martinez-Flor, 2006).

Some researchers believe that the selection of situations must not be based on only the researchers' imagination or intuition (Rose, 2009; Kasper, 2000) and pragmatic questionnaire must be assessed to meet some specific features, i.e. their likelihood, relevance, context variables because at the end it is the analysis of the responses to those situations which is taken into account and not the researchers' assessment (Rose, 2009). For this purpose and to ensure the likelihood and relevance of situations in Malaysian context, the questionnaires were piloted using Cheng's (2005) perception questionnaire to guarantee the familiarity of Malay participants with the situations of the questionnaire. The perception questionnaire in the form of Likert scale aimed to elicit the respondents' perception of the rate of offensiveness, likelihood of the situation, and if they have ever been in the same situation or not (see Appendix). In other words, the findings of the likert scale established certainty as for the familiarity and likelihood of the situations in the DCT to Malay respondents and the extent to which they would be socially and culturally appropriate for the target population (e.g. in this study Malaysian context). These factors in a DCT (i.e. familiarity, likelihood and relevance) have always been the researchers' main concern (Demeter, 2000). The analysis of Likert scale showed the relevance and likelihood of the situations in Malaysian context. The final questionnaire consisted of three sections: the first section included respondents' biodata (age, gender, education, etc.) whose results were explained in previous section. The second part of the questionnaire consisted of 6 situations in an open-ended questionnaire in the form of discourse completion task (see Appendix A). The contextual variables varied across the situations: three situations (book store, cloth store and supermarket) have the contextual variables of high social status and high social distance relative to the participant. The other three situations (bus, cinema and library) have the contextual variables of equal social status and low social distance relative to the participant.

The second part of the questionnaire was a structured-interview which aimed to explore the respondents' perception of politeness and language of thought i.e. language the participants think in when producing response, in responding to rudeness. The participants were asked what exactly they were paying attention to when they want to reply to somebody who offends them with regard to variation in contextual variables (i.e. social status and social distance). The other question addressed the participants' language of thought. They were asked what language they were thinking of in responding to an offensive situation, e.g. English, Malay, etc. and whether they switched their language of thought at some point during of their responses.

\section{Procedure}

After pilot study, the final questionnaire was collected from a voluntary participation of 60 Malaysians university students at University Sains Malaysia, Penang, Malaysia. The participants were met after their classes or at university libraries and they were invited to participate in the research. The participants were asked to complete the DCT questionnaire and to attend a follow-up semi-structure interview. Each participant was met individually by the researchers at USM. Researchers provided the subjects with detailed instructions about the tasks. Each participant was given 30 minutes to complete the provided task. Participants were first presented with written DCT situations where they were asked to write what they would say under each situation. To preserve the homogeneity of the participants, the questionnaires were only collected from Malaysians Malay university students. The necessary instruction such as how to answer the questionnaire was presented by the researchers and one example was given. Following the completion of the questionnaire, the researchers conducted the structured interview (around 15 minutes) to elicit the respondents' perception toward the effect of contextual variables, i.e. social status and social distance, on responding to rudeness. The interview was recorded and then analyzed and interpreted by the researchers. The findings are explained in the following sections.

\section{Data analysis}

This section reports on the analysis of the DCT questionnaire and the findings of the structured interview. 


\subsection{DCT questionnaire}

After the data were collected, they were analyzed and classified based on a coding scheme adopted from Beebe and Waring's (2005) study of responding to rudeness. The coding scheme comprises twelve strategies. The strategies are as follows:

1. Insult

"How can you answer it such a dummy manner? You must be a fool."

2. Threat

"I want to talk to the manager of this stor."

3. Challenge

"But I want to see THAT book."

4. Criticize

"You're giving a bad example for your childe."

5. Compliment/ Greet (sarcastic)

"You're really kind..."

6. Argue (take issue)

"I have a right to see that book even if I don't have intention to purchase it."

7. Justify

“....but I'm not from here and I don't want to be lost."

8. Request

"Could you draw the directions for me?"

9. Aplogize

"I'm sorry. It's my fault."

10. Thank

"Okay, thank you."

11. Acquiesce

"Okay, yes, sir. I will try."

12. Opt out

Nonverbal: Say nothing.

Verbal: "Never mind." "Whatever."

The questionnaires were then analyzed based on the coding scheme. The results are demonstrated in table 1:

Table1.Frequency of strategies for the act of responding to rudeness

\begin{tabular}{lcclcc}
\hline Strategy & Frequency & Percentage & Strategy & Frequency & Percentage \\
\hline Insult & 73 & $9.60 \%$ & Justification & 54 & $6.90 \%$ \\
Threat & 6 & $0.75 \%$ & Request & 106 & $13.55 \%$ \\
& & & Persisting & Total & 24.95 \\
Challenge & 69 & $8.85 \%$ & Apology & 105 & $13.45 \%$ \\
Criticism & 59 & $7.55 \%$ & Thanking & 33 & $4.20 \%$ \\
Compliment/agreement & 97 & $12.40 \%$ & Acquiesce & 56 & $7.15 \%$ \\
Aggressing strategies & Total & 39.15 & & & \\
Argument & 35 & $4.50 \%$ & Opt-out & 87 & $11.15 \%$ \\
& & & Acquiescing & & $35.95 \%$ \\
& & & & $\mathrm{~N}=780$ & $100 \%$ \\
\hline
\end{tabular}

The data were first analyzed in terms of the frequency of strategies across all situations. The findings showed that request, apology and compliment (sarcastic) were the first three most frequently used strategies across the situations. The findings also demonstrated that acquiesce, justification, argument, thanking and threat received the lowest frequency across the questionnaire respectively.

Some of the examples of the strategies elicited from the questionnaires are as follows:

Challenge

English

I am also one of your customers. So, you should also respect me as your customer.

Malay

Saya pun salah seorang pelanggan awak. Jadi awak perlu menghormati saya sebagai pelanggan awak. 


\title{
Criticism
}

English

I just ask you to hand over the books only.

Malay

Minta tolong ambil ja pun.

Argument (taking the issue)

\section{English}

I was just asking you to hand over the books. That also can't be done? I was asking in a polite manner only. Malay

Takkan nak sua buku tu pun tak boleh pakcik? Saya mintak elok-elok ja kot?

\section{$\underline{\text { Request }}$}

English

Can you help me? I'm also your customer in this shop, but if you can't help me, it's ok. There are still many bookstores that I can go to.

Malay

Boleh tak tolong saya?sy juga pelanggan dalam kedai nih..tapi kalau pakcik xleh tolong sy takpelah..banyak lagi kedai buku yg sy boleh pergi"

\author{
$\underline{\text { Apology }}$ \\ English \\ Okay, sorry. \\ Alright, brother. I'm sorry. \\ Sorry. \\ Oh, I'm sorry, uncle \\ Malay \\ Okay sorry. \\ Orait bang. Sori... \\ MINTA MAAF \\ owh, saya minta maaf pak cik
}

\section{Thanking}

English

Oh, is it? Thank you

Oh, it's okay. Thank you

Fine. Thank you

Okay, thank you

Malay

oooo,,yeke....tq

Oh..tak pe lah, terima kasih

Baiklah terima kasih

Ok, terima kasih

\section{Acquiesce \\ English \\ Okay \\ Malay \\ Ok}

\section{Opt-out}

English

Oh, never mind, if it's like that, I will take the book.

Never mind if that's the case.

Never mind, if you really can't help, I'll find myself.

Never mind if it is like this.

\section{Malay}

oh tidak mengapa, kalau begitu saya akan ambil buku itu

Takpelah kalu macam tu

Takpela kalau tak boleh..saya akan cari sendiri

Tidak mengapa kalau begitu 
In general, the data displays that the respondents use aggressing strategies, i.e. insult, threat, challenge, criticism, compliment, greeting (\# 39.15\%) more frequently than acquiescing strategies, i.e. argument, justification, request (\# $35.95 \%$ ) and persisting strategies ,i.e. apology, thanking, acquiesce, opt-out (\# 24.95\%).

The data were then analyzed in terms of the use of strategies with variation in contextual variable, i.e. social status and social distance. Table 2 presents a summary of the findings for the situations with high social status (i.e. the offender is older than the respondents) and high social distance (i.e. the respondent does not know the offender).

Table 2. Frequency of strategies in high social status and high social distance situations

\begin{tabular}{lcclcc}
\hline $\begin{array}{l}\text { Strategy (high } \\
\text { status) }\end{array}$ & Frequency & Percentage & Strategy & Frequency & Percentage \\
\hline Insult & 53 & $13.40 \%$ & Justification & 21 & $5.30 \%$ \\
Threat & 5 & $1.25 \%$ & Request & 23 & $5.80 \%$ \\
Challenge & 37 & $9.35 \%$ & Apology & 44 & $11.10 \%$ \\
Criticism & 37 & $9.35 \%$ & Thanking & 28 & $7.10 \%$ \\
Compliment & 49 & $12.35 \%$ & Acquiesce & 34 & $8.55 \%$ \\
Argument & 14 & $3.55 \%$ & Opt-out & 51 & $12.90 \%$ \\
& & & & $\mathrm{~N}=396$ & $100 \%$ \\
\hline
\end{tabular}

As displayed in table 2, insult is the most frequently used strategy across the high social status and high social distance situations. Opt-out, compliment and apology strategies were the second to fourth frequently used strategies in these situations. The findings showed that participants used challenge and criticism equally in the high social status situations. Acquiesce, thanking, justification request and argument strategies were the sixth to tenth frequently used strategies in these situations. The analysis showed that threat strategy was the least frequently used strategy in these situations.

An analysis of the strategies in situations in with equal social status and low social distance relative to the respondents are presented in table 3 .

Table 3. Frequency of strategies in equal social status and low social distance situations

\begin{tabular}{lcclcc}
\hline $\begin{array}{l}\text { Strategy (equal } \\
\text { status }\end{array}$ & Frequency & Percentage & Strategy & Frequency & Percentage \\
\hline Insult & 20 & $5.20 \%$ & Justification & 33 & $8.60 \%$ \\
Threat & 1 & $0.25 \%$ & Request & 83 & $21.60 \%$ \\
Challenge & 32 & $8.35 \%$ & Apology & 61 & $15.90 \%$ \\
Criticism & 22 & $5.75 \%$ & Thanking & 5 & $1.30 \%$ \\
Compliment & 48 & $12.5 \%$ & Acquiesce & 22 & $5.70 \%$ \\
Argument & 21 & $5.45 \%$ & Opt-out & 36 & $9.40 \%$ \\
& & & & $\mathrm{~N}=384$ & $100 \%$ \\
\hline
\end{tabular}

As displayed in table 3, request was the most frequently used strategy in situations which the offender happened to be the participant's classmate and is known to the participant. The findings showed that apology, compliment, justification, opt-out, challenge, criticism and argument were the second to tenth frequently used strategies respectively. According to table 3, thanking $(\mathrm{n}=5)$ and threat $(\mathrm{n}=1)$ were the least frequently used strategies in these situations.

\subsection{Structured interviewed}

A structured interview was conducted after the questionnaire data were collected. The first question addressed the respondents' perception about what they would mainly attend to when they want to respond to somebody in a rude or offensive situation targeted at them and whether variations in variables such as social status or social distance would affect their responses.

From 51 respondents, the majority of respondents stated that it would definitely affect the way they respond to rudeness of the offender if he or she is of the same age or older than them and if the offender knows them or does not know them. According to one of the respondents, "I was paying attention to age factor when I wanted to somebody in a rude or offensive situation". However, few respondents stated that it would not affect the way they respond to rudeness. One of the respondents stated in a response:

"Sometimes, when the situation is too rude, I will not take in the factor of age, but just reply accordingly. This means that if the person is rude, I will be rude. If he is sarcastic, I will reply sarcastically, as well". 
The factors that might influence their responses were age, rank or position, level of rudeness, people, religion, the way the offender reprimands, the way of the offender's mistakes, the way of communication, gender, intonation of the communication, situation, character, emotion, environmental conditions, and race. Some respondents mentioned that age was the factor, and some others commented that people were the factor. For factors, such as situation and the way of communication, few respondents mentioned each factor. A few respondents stated that gender was the factor. Few others conveyed that level of rudeness was the factor. For factors, such as rank or position, religion, the way the offender reprimands, the way of the offender's mistakes, intonation of the communication, intention of the communication, character, emotion, environmental conditions, and race, few respondents mentioned each factor. The respondent, who stated people were the factor, mentioned this in a response:

"It's always the people that are one of the factors. I don't mind if the people, who are close to me, are quite harsh to me because I can accept, but if the people, who are not close to me and are quite rude, I will definitely reprimand them".

However, the respondent, who stated that religion was the factor, mentioned this in a response:

"I always have to think before acting harshly because I need to take in religion into account when it comes to responding to rudeness. This is because my actions and attitude reflect on my religion clearly and I do not want other people to look at my religion in a negative manner".

Respondents stated that they would take care of their speech in an interaction with people of higher social status (e.g. older than them) in order to show that they respect the older people. According to one of the respondents, "I will give less of a rude response if the offender is much older due to the respect given to the offender, thus I will try to take care of my speech with that person". If the person that the respondents were talking to is a classmate or a stranger, they would talk normally, but if they did not know the person at all, the conversation would be more formal. One of the respondents stated this: "I would give response by analysing the offence first or the rude words that had been uttered or the offence that had been done by the offender". This means that the level of rudeness did not affect that much, but if it is too rude, the respondents would respond back. When the offender was the respondents' classmate or older friend/person, the respondents would try to compromise. If the offender was a stranger, the respondents would respond back nicely, but if the offender was committing an offence in an extreme manner, the respondents would scold back. Some respondents agreed that for older people or kids, their level of rudeness was forgiven, but if the level of rudeness was too high or extreme, the age factor was not considered anymore. One of the respondents stated this in a response:

"Usually, the behaviour of the offender that is rude will cause me to give the response that is not good because if the offender is really rude, I will follow the way the offender talks by responding back rudely".

However, there was a respondent, who stated this in a response: "If the offender is too rude, he or she will not bother the offender because it is a completely waste of time". This means that the respondent will just opt out when exposing to these situations.

The respondents were then asked about their language of thought and whether they would think in Malay or English first in preparing their responses.

From 51 respondents, the majority of the respondents stated that they were thinking first in Malay when they responded with these situations. One of them stated: "It's easier for me to think in my mother tongue, which is Malay when I want to respond to these situations". Few of the respondents, on the other hand, stated that they were thinking first in English when they were exposed with the rude situations. According to a respondent,

"I've studied abroad for quite awhile before coming back to Malaysia. I guess I'm used to talk in English more, thus I will automatically think in English first when I want to respond with these situations".

Some of the respondents, however, conveyed that they were thinking in both Malay and English when they were responding to the situations. A respondent mentioned this: "Normally, I will speak in both Malay and English at home. It's normal for me to think in both Malay and English when I am exposed to these situations".

Following this question, the respondents were asked whether they switched their language of thought at some point during of their responses. The majority of respondents stated that they did switch their language of thought at some point during their responses. From the respondents, who stated that they did switch their language of thought at some point during their responses, few respondents stated that they switched from English to Malay, while a few others stated they switched from Malay to English. Some respondents, however, stated that they did not switch their language of thought at any point during their responses. A few of the respondents switched their language of thought depending on the situations. Some respondents probably switched their language of thought without them knowing during their responses. There was a deviant case, whereby some respondents did not switch their language of thought, but they were using English and Malay during their responses, as they were thinking on these two languages together.

\section{Discussion}

The findings of this study display that request is the most frequently used strategy by Malays. Moreover, apology and compliment are the second and third frequently used strategies by Malays. Rude people are everywhere. They ruin people's days with their rude comments and bad attitudes. This is not the intention of every rude person, though. Oftentimes, people are only being rude because they have had a bad day. There are effective ways to deal with rude people, without being mean. The factors that might influence their responses were age, rank or position, level of rudeness, people, religion, the way the offender reprimands, the way of the offender's mistakes, the way of 
communication, gender, intonation of the communication, situation, character, emotion, environmental conditions, and race. Age factor will definitely be taken into consideration when the respondents want to address the offender because most of the respondents agree that it is the factor when it comes to responding to rudeness.

Usually, the respondents will always take care of their speech when they talk to people, so as not to evoke any conflicts in the conversations. This is taken from the interview with the respondents. The best way to deal with rude people is to ignore their rudeness by apologising although the respondents are not wrong when they are responded to rude situations. This shows that they show respect to the person that they are responding to. Apologising, when responding to rudeness, will help to resolve any tension between the respondents and the person, who is rude if the situation requires it. An apology can be the beginning of a resolution. When a person apologises, it will soften the rude person's response. It is important to use manners to overcome the person's rudeness. This is because most people, especially rude people would be taken aback by this approach and would quickly backtrack to reassure the respondents that the respondents have not offended them.

When the offender is the respondents' classmate or older friend/person, the respondents will try to compromise. When someone the respondents know personally is being rude, the respondents will talk to the person about it. The offender should know that the respondents feel that the way he/she treated the respondents was rude and unnecessary, since he/she may not have done it intentionally. There is also a possibility the respondents were unknowingly rude and he/she just reacted. If that is the case, the respondents should apologise.

From Table 1, it could be seen that request shows the highest frequency, while apology shows the second highest frequency, and compliment shows the third highest frequency. All of these are frequencies for acts responding to rudeness.

From all the situations that had been mentioned, some people say some rude words or complain negatively as a way of crying for help even though they may not be conscious of it. The respondents normally calm down the offender by taking the onus to lend a helping hand by just simply stating some requests, which can soften the offender's rude ways of responding to the respondents. Simple requests can actually do wonders. This is because the offender might be busy or he/she is in the middle of doing something, thus he/she responds rudely to the respondents. Therefore, some requests stated by the respondents might help to ease the offender's burden. However, sometimes, the respondents give their requests to the offender, so that the offender is aware that he/she needs to respond politely, instead of being rude. This is the so-called awakening call for the offender to behave appropriately. It is one of the persisting strategies that will make the offender knows that he/she is in the wrong. This is because the offender might not know that he/she is behaving rudely; therefore, requests are normally made by the respondents, so that the situations will be better. People these days need reminder to be polite from time to time. This will enable the offender to behave in an appropriate manner when he/she is conversing with the respondents. This is not to undermine people, but to make sure the conversation will be carried out in the way it is supposed to be.

Some situations are meant to be solved without conflicts. The respondents would apologise when they are exposed to rude situations. Nonetheless, if the level of rudeness is too extreme especially when the respondents had already apologised, the respondents will definitely scold back. This does not happen frequently, only when the situations got worst.

Most of the time some situations are meant to be complimented or greeted sarcastically because those rude acts that the offenders did, need to be reprimanded sarcastically, so the offender will be aware that he or she is actually rude in responding to the respondents. Complimenting or greeting the offender's rudeness or bad behavior in a sarcastic way will catch the person off guard and he or she does not know what to say. Sometimes, the offender will be speechless when the respondents chastise him or her in a way that reminds his or her rudeness and mistakes. On the other hand, sometimes the respondents become sarcastic in the way they compliment or greet when they are irritated by the offender's rude behavior, scared by the way the offender reacts, or just having a bad day, and other times, they do it when they are surrounded by rude people or exposed with rude situations. Sarcasm can be in the form of insult, but it is a mild form of insult because insult is an expression, statement (or sometimes behavior), which is considered degrading and offensive, while sarcasm is an expression by the respondents actually being scared of the rude situations/offender's rude behavior or they are exposed to the rude situations that they do not know how to deal with, so this is how they learn to deal with it. Sarcasm can also be done intentionally (doing it just for fun) or unintentionally (irritated or agitated when people are in a bad mood and they are exposed to rudeness). Most sarcastic comments are, when taken literally, the opposite of what is intended. It is the respondents' tone that gives the sarcasm away.

Table 2 shows the frequency of strategies in high social status and high social distance situations. This means that the offender has a high social status and the social distance between the offender and the respondent is high because the respondent does not know the offender. From Table 2, insult, opt out, and compliment show the three highest frequencies. Table 3 shows the frequency of strategies in equal social status and low social distance situations. This means that the respondent knows the offender because the social distance between the offender and the respondent is low. From Table 3, request, apology, and compliment show the three highest frequencies, while opt out is ranked fifth and insult is ranked tenth in the table. This means that social status and social distance do not really play a part in responding to rudeness because from the results, it seems that the respondents react harshly or rudely and the situations are really rude, but when the situations are not really that rude, they will give a chance and not respond that rudely. According to the respondents, situations 1 to 3 are considered really rude compared to situations 4 to 6 , thus the speech act responding to rudeness varies. 
From the structured interview, most of the respondents were thinking first in Malay when they were responded with rude situations. Most of the respondents also switched their language of thought from English to Malay. That is why the frequencies of apologise, request, and opt out are the highest among the 12 pragmatic strategies. This is because Malay language is considered to be the most polite language compared to English and any other languages. This is in line with Song $(2012$, p. 32) who maintained that "cultural differences do play a role in perceptions of social factors between communicators. For instance, an old man and a young boy in the Western society can be friends". However, the case is different in East Asia culture where the interpersonal relationship can be more formal due to the hierarchical nature of the culture. This means that in Malay culture, it is not possible to have a friendship between communicators of different age in a casual format. Song (2012, p. 32) further indicated that "some East Asian languages even utilize verbal conjugations or different words and phrases to show respect to elders, which leads to a more formal and longitudinal relationship". Indeed, Malay language has its importance in giving an understanding for the politeness patterns of the Malays in Malaysia. The Malay language is influenced by its Malay culture, which emphasises self-control in the face of social conflict, hence uttering displeasure or disagreement is less likely to happen. The polite system of the Malays is deeply rooted in the "budi" complex. According to Teo (1996), Malays rely on indirectness in many common social situations, especially when they are trying to be polite Nonetheless, not all Malays are polite. There will be some, who are impolite, but not too impolite compared to the people from the international countries, such as the European countries, Iran, Arab, and so forth.

Most of the respondents agreed that response to rudeness depends on culture, religion, family influence, way of surroundings, and social environment. It will be really sad to see the Malays being rude because they were taught and nurtured to be polite since young. Nevertheless, some Malays were not taught properly since young to be courteous and well-mannered. Therefore, we could see that some of them not portraying the correct behavior that they are supposed to be.

If someone in a customer service position is rude to the respondents, they should try being excessively nice in return by looking at him/her in his/her eyes, calling him/her by his/her name and smiling. If the offender is a naturally rude person, the respondents will be killing the offender with kindness. If the person is just having a bad day, the respondents will make it better by being nice. The favour may even be returned the next time when the respondents are having a bad day too.

\section{Limitation and suggestions for further studies}

Despite the fact that the present study has contributed to the body of research some valuable findings yet there are some limitations. Although the findings of this study have given interesting insight, there are some limitations to the study. First, the findings of this study cannot be generalized to the culture of all Malaysians due to the number of respondents. Moreover, the present study only includes one Malaysian ethnicity. Therefore, other studies with more respondents and with other Malaysian ethnicities (i.e. Chinese, Indian) are suggested.

DCTs can provide researchers with reliable information on speakers' pragmalinguistic feature to provide information on the use of strategies and linguistics form, as well as sociopragmatic knowledge, which all provide information on the use of their use of contextual favours under which certain strategies and linguistic choices (However, Kasper and Rose, 2002). However, responses in DCTs cannot be compared with actual production data (Tran, 2004, cited in Tran, 2006) since they reflect only what participants think they should say (Boxer, 1996), not what they actually say in reality. Therefore, it is suggested to use other instruments to ensure of the reliability of the findings (oral DCT, role play).

\section{Conclusion}

Language is an integral part of our everyday life. People use language to transmit their ideas and thought and to communicate with each other. The appropriate use of language, however, is sometimes dependent on the context it is used to respond and be understood correctly. The appropriate use of language differs from one culture and context to another. This paper addressed the issue of impoliteness by studying the act of responding to rudeness by a group of Malaysian university students. The objectives of this study were to examine Malaysian university students' productions and perceptions of responding to rudeness. It was a preliminary study to figure out what strategies Malay university students use in responding to an offensive language directed at them. The findings displayed that the respondents used the same types of strategies (e.g. threat, challenge, insult, etc.) in situations with variation in contextual variables (i.e. social status, social distance); however, the patterns of frequency of strategy use were different in such situations.

The significance of this study can be discussed from different perspectives. First, the speech act of responding to rudeness may serve as an illuminating source of information on the socio-cultural values of a speech community and provide important insights into the social norms that are embedded in cultures. It is believed that the findings of this paper provides us some examples of the way Malays responding to offensive situations in Malaysia and in this way potentially contribute to devising better strategies for the development of communicative competence and broaden our knowledge of language and culture in Malaysia.

Second, the present study adds to the literature already existence in specifically the area of cross-cultural pragmatics, i.e. the investigation of responding to rudeness within the Malaysian context. There is no single empirical study that has looked at the specific speech act of responding to rudeness by Malaysians. Hence, this study fills an existing gap in pragmatic research and lays a foundation for more studies that focus on Malaysians speech act production, comprehension, and development. 
With regard to pedagogical implications, it is believed that the current analysis would be useful in the field of language teaching and language learning. For example the use of DCT as an assessing instrument might be useful in classroom where learners would be exposed to the way various speech acts are realized and produced including responding to rudeness. This would help raising learners pragmatic awareness of different culturally factors related to the realization of speech acts. A DCT provides learners with an opportunity practice the performance of speech act in a low -pressure situation in contrast to face to face interactions where the pressure is high demanding learners to respond more spontaneous. Using DCT as a tool in the class would help teachers to get an insight "on the state of learners' discourse production systems or the extent to which available pragmatic knowledge is readily accessible in conversation" (Bergman and Kasper, 1993, p.101). Finally, this study has the potential to benefit language teachers and ESL curriculum and textbook designers. Language teachers can use the findings to anticipate and thus reduce the incidence and severity of situations where in learners experience cultural and language miscommunication that leads to communication breakdown.

It might not be an exhaustive study of this piece of language function; however, it is believed that the findings of this paper can take us to understand some culture-specific features of responding to offensive situations in Malaysia and in this way potentially contribute to devising better strategies for the development of communicative competence and broaden our knowledge of language and culture in Malaysia.

\section{References}

Arendholz, J.(2013). Appropriate online behavior: A pragmatic analysis of message board relations. Amsterdam; Philadelphia: John Benjamins Publishing Company.

Asma Abdullah. (1996). Going global: Cultural dimensions in Malaysian management. Kuala Lumpur: Malaysian Institute of Management.

Asmah Haji Omar. (1992). The linguistic scenery in Malaysia. Kuala Lumpur: Dewan Bahasa dan Pustaka.

Austin, J. L. (1962). How to do things with words. Oxford: Oxford University Press.

Beebe, L. M. (1995). Polite fictions: Instrumental rudeness as pragmatic competence. In: James E. Alatis, Carolyn A. Straehle, Brent Gallenberger and Maggie Ronkin (eds.) Linguistics and the Education of Language Teachers: Ethnolinguistic, Psycholinguistics and Sociolinguistic Aspects. Georgetown University Round Table on Languages and Linguistics. (pp. 154-68), Georgetown: Georgetown University Press.

Beebe, L. M., \& Waring, H. Z. (2005). Pragmatic development $n$ responding to rudeness. In J. M. Frodeson \& C. A. Holten (Eds.), The power of context in language teaching and learning. Festschrift in honor of MArianne Celce-Murcia (pp. 67-79). Boston, MA: Heinle and Heinle.

Blum-Kulka, S. (1982). Learning to say what you mean in a second language: A study of Hebrew as a second language. Applied Linguistics, 3, 29-59.

Boxer, D. (1996). Ethnographic interviewing as a research tool in speech act analysis: The case of complaints. In S. M. Gass \& J. Neu (Eds.), Speech acts across cultures: challenges to communication in a second language (pp. 217-239). Berlin; London: Mouton de Gruyter.

Cheng, S. W. (2005). An exploratory cross-sectional study of interlanguage pragmatic development of expressions of gratitude by chinese learners of English. (Unpublished doctoral dissertations, The University of Iowa).

Cohen, A. (1996). Speech acts. In S. L. McKay \& N. H. Hornberger (Eds.), Sociolinguistics and language teaching (pp.383-420). Cambridge: Cambridge University Press.

Cohen, A., \& Olshtain, E. (1981). Developing a measure of sociolinguistic competence: The case of apology. Language Learning, 31, 113-134.

Culpeper, J. (2011). Impoliteness: Using language to cause offence. Cambridge: Cambridge University Press.

Dahlan, H. M. (1991). Local values in intercultural management. Malaysian Management Review, 1, 45-50.

Demeter, G. (2000). A pragmatic study of apology strategies in Romanian. (Unpublished Master thesis, Oklahoma State University).

Dietz, J. L. G., \& Widdershoven, G. A. M. (1991). Speech acts or communicative action? In L. Bannon, M. Robinson \& K. Schmidt (Eds.), Proceedings of the Second European Conference on Computer-Supported Coopemtive Work (pp. 235-248). Amsterdam, Netherlands.

Farnia, M., Buchheit, L., \& Vedaei, M. (2010). "Move away so I can hear": Iranians and Americans' responses to rudeness- A pilot study. International Journal of Humanities, 8(4), 51-63.

Eisenstein, M., \& Bodman, J. W. (1986). "I very appreciate": expressions of gratitude by native and non-native speakers of American English. Applied Linguistics, 7(2), 167-185.

Hymes, D. H. (1972). On communicative competence. In B. Pride \& J. Holmes (Eds.), Sociolinguistics (pp. 269-293). Harmondsworth: Penguin.

Jamaliah Mohd. Ali. (1995). Indirectness in Malay diplomacy (with particular reference to business dealings and labor relations). Jurnal Bahasa Moden, 9, 19-28. 
Jamaliah Mohd. Ali. (2002). Why we don't say what we mean: A study of verbal indirection in communication. Jurnal Bahasa Moden, 14, 33-44.

Kasper, G. (2000). Data collection in pragmatics research. In H. Spencer-Oatey (Ed.), Culturally speaking:managing rapport through talk across cultures (pp. 316-341). London: Continuum.

Kasper, G. \& Rose, K. (2002). Pragmatic development in a second language. Oxford: Blackwell.

Goffman, E. (1967). Interaction ritual: Essays on face-to-face interaction. Oxford, England: Aldine.

Lakoff, R. T.(1989) The limits of politeness: Therapeutic and courtroom discourse. Multilingua 8 (2-3), 101-129.

Lee, S. K. (2003). Exploring the relationship between language, culture and identity. GEMA Online TM Journal of Language Studies, 3(2), 1-13.

Manes, J. (1983). Compliments: A mirror of cultural values. In N. Wolfson \& E. Judd (Eds.), Sociolinguistics and language acquisition (pp. 96-102). Rowley, MA: Newbury House.

Maros, M. (2007). The social functions of complaints in a Malay speech community. SEALS17

Martinez-Flor, A. (2006). Task effects on EFL learners' production of suggestions: A focus on elicited phone messages and Emails. Journal of English and American Studies, 33, 47-64

Murphy, B., \& Neu, J. (1996). My grade's too low: The speech act set of complaining. In S. M. Gass \& J. Ne (Eds.), Speech acts across cultures: Challenges to communication in a second language (pp. 191-216). Berlin: Mouton de Gruyter.

Olshtain, E., \& Cohen, A. D. (1983). Apology : A speech act set. In N. Wolfson \& E. Judd (Eds.), Sociolinguistics and Language Acquisition (pp. 18-35). Rowley: Newbury House.

Rose, K. R. (2009). Interlanguage pragmatic development in Hong Kong, phase 2. Journal of Pragmatics, 41, 23452364.

Scollon, R., \& Scollon, S. (1997). Intercultural communication. Oxford, UK: Blackwell Publisher.

Song, S. (2012). Politeness and culture in second language acquisition. Great Britain: Palgrave MacmPALGRAVE MACMILLAN.

Spencer-Oatey, H. (2000). Rapport management: A framework for analysis. In H. Spencer-Oatey (Ed.), Culturally speaking: Managing rapport through talk across cultures (pp. 11-46). London and New York: Continuum.

Storz, M. L. (1999). Malay and Chinese values underlying the Malaysian business culture. International Journal of Intercultural Reatiol. 12(1), 117-131.

Teo, K. S. (1995). Tahu bahasa/Tak tahu bahasa: Persoalan bahasa, budaya dan komunikasi. In Hanapi Dollah \& Lokman Mohd. Zen (eds.), Kebudayaan Melayu di ambang Abad Baru: Satu Himpunan Makalah, (Malay Culture in the new millenium: A Collection of articles), (pp. 273-288). Bangi: Jabatan Persuratan Melayu.

Teo, K. S. (1996). The acquisition of Malay as a second language: A case of the essentiality of culture learning. A paper presented at Southeast Asian Linguistics Society VI, May 10 - 12, University of Oregon, Eugene, USA.

Tham. S. C. (1971). Tradition, values and society among the Malays. Review of Southeast Asian Studies, 4, 10-20

Tran, G. Q. (2006). The naturalised role-play: An innovative methodology in cross-cultural and interlanguage pragmatics research. Reflections on English Language Teaching, 5(2), 1-24.

Westacott, E. (2006). The rights and wrongs of rudeness. Published in International Studies in Applied Philosophy, 20(1).

\section{Appendix A:}

1. Anda berjalan ke dalam stor buku. Buku-buku yang anda minat untuk diperiksa terletak atas rak-rak buku belakang penjual buku. Anda menanyakan penjual buku, iaitu seorang lelaki yang lebih tua daripada anda dan anda TIDAK mengenalinya untuk memberikan anda satu atau dua daripada buku-buku tersebut. Selepas melihat beberapa muka surat, anda menanyakannya untuk memberikan anda buku yang satu lagi. Pada ketika ini, dia menjawab anda: "Saya tidak boleh menolong anda terlalu banyak- Saya mempunyai pelanggan-pelanggan yang lain!"

Anda akan kata:

“

Sekiranya anda tidak dikawal oleh tekanan sosial: Anda akan rasa seperti mengatakan kepadanya? “ 
2. Untuk membeli-belah, anda pergi ke pasar raya yang besar dan berdiri dalam barisan yang panjang untuk meninggalkan pasar raya tersebut. Bagaimanapun, seorang pelanggan yang lebih tua yang anda TIDAK mengenali, menolak dan berdiri di depan anda. Apabila anda menuduhnya kerana memotong barisan, dia memberitahu anda: "Saya berada di depan anda dahulu--anda hanya tidak nampak saya!"

Anda akan kata:

(.............................................."

Sekiranya anda tidak dikawal oleh tekanan sosial: Anda rasa seperti mengatakan kepadanya?

3. Anda pergi ke butik untuk membeli beberapa baju. Setelah anda menanyakan kerani, iaitu seorang lelaki yang lebih tua dan anda TIDAK mengenali untuk menunjukkan beberapa baju, anda kecewa apabila anda mengetahui yang tiada yang memenuhi kesukaan anda. Apabila meninggalkan tempat tersebut, anda terdengar kerani tersebut memberitahu rakan-rakan sekerjanya, "Pelanggan lain, hanya membuang masa kami".

Anda akan kata: “.

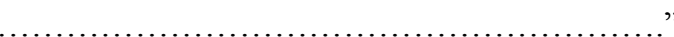

Sekiranya anda tidak dikawal oleh tekanan sosial: Anda rasa seperti mengatakan kepadanya? "

4.Anda sibuk membaca di perpustakaan, dan beberapa rakan sekelas anda yang anda mengenali mereka dengan baik sedang bercakap dengan kuat pada meja sebelah. Apabila anda mengadu tentang kebisingan mereka, seorang daripada mereka mengatakan: "Minta maaf, anda boleh menukar tempat duduk kamu sekiranya anda tidak gembira di sini".

Anda akan kata:

Sekiranya anda tidak dipengaruhi oleh tekanan sosial: Anda rasa seperti mengatakan kepadanya?

5. Anda telah pergi ke pawagam. Dua orang yang baru berkahwin, iaitu kebetulannya ialah rakan-rakan sekelas anda dan anda mengenalinya dengan baik, duduk di belakang anda, mula berbisik dan ketawa, dan sebagai akibatnya,anda tidak boleh dengar filem itu. Apabila anda melihat ke belakang untuk menunjukkan mereka yang anda adalah kecewa, lelaki muda itu memberitahu anda: "Boleh saya bantu anda?"

Anda akan kata:

Sekiranya anda tidak dikawal oleh tekanan sosial: Anda rasa seperti mengatakan kepadanya?

6. Anda menaiki bas yang sesak. Membawa beg yang besar, anda cuba untuk melepasi jurang yang sempit di antara penumpang-penumpang untuk pergi ke pintu depan. Tiba-tiba seorang penumpang, iaitu kebetulannya rakan sekelas anda dan anda mengenalinya dengan baik, memberitahu dengan kasar, jelasnya kepada anda, "Saya rasa anada tidak pernah dengar perkataan 'maafkan saya".

Anda akan kata:

Sekiranya anda tidak dikawal oleh tekanan sosial: Anda rasa seperti mengatakan kepadanya? 